\title{
PENGARUH KEADILAN ORGANISASI TERHADAP KEPERCAYAAN ORGANISASI \\ (STUDI EMPIRIS PADA SELURUH SEKOLAH TINGGI ILMU EKONOMI DI KOTA PEKANBARU
}

\author{
Adi Rahmat ${ }^{1}$, Hadiyati ${ }^{2}$, Muhammad Rasyid Abdillah ${ }^{3}$ \\ ${ }^{1,2,3}$ Fakultas Ekonomi Universitas Lancang Kuning \\ Jln. D.I. Panjaitan KM 8 Rumbai Pekanbaru \\ E-mail : adirahmat@unilak.ac.id
}

\begin{abstract}
The purpose of this research is to know the effect of distribution of justice, procedural justice, and interactical juastice to organizational trust. Population in this research is all lecturer at high school of economics. The sample collection of 104 people. Data processing is done by structural equation modeling analysis using WarpPLS 5.0 software. The results showed that organizational justice had positive effect on organizational trust. This explains that subordinates who feel justice in their organization will lead them to believe in their organization.
\end{abstract}

Keywords: Distributive Justice, Procedural Justice, Interactional Justice, Organizational Trust

\section{PENDAHULUAN}

Selama satu dasawarsa terakhir, keadilan organisasi dan kepercayaan pada organisasi sudah menjadi perhatian para ilmuan dan praktisi studi organisasi (Tlaiss dan Elamin, 2015), terutama berkaitan dengan dampaknya terhadap efektivitas organisasi dan keinginan para karyawan untuk kooperatif dan produktif dalam organisasi (Aryee et al., 2002; Wong et al., 2002; Moye and Henkin, 2006; Wong, 2012). Misalnya, penelitian yang dilakukan oleh Cheng (2014) menemukan bahwa keadilan organisasi yang dirasakan oleh karyawan menjadi penyebab tingginya tingkat komitmen organisasi karyawan.

Selanjutnya, penelitian yang dilakukan Moye and Henkin (2006) menyimpulkan bahwa kepercayaan terhadap organisasi memberikan banyak manfaat bagi sebuah organisasi. Menurut Moye dan Henkin, kepercayaan karyawan terhadap organisasinya menjadi dasar dalam hubungan interpersonal yang baik sehingga mampu menciptakan kooperatif dan komunikasi yang efektif.

Beberapa penelitian yang berhubungan dengan keadilan organisasi dan kepercayaan organisasi hanya membahas dampak keduanya terhadap perilaku-perilaku yang dihasilkan karyawan dalam organisasi seperti dampak keadilan organisasi terhadap workplace deviance (Liu and Ding, 2012), dampak keadilan organisasi terhadap organizational citizenship behavior (Gupta and Sing, 2013; Elamin and Tlaiss, 2015), atau dampak kepercayaan organisasi terhadap komitmen organisasi dan intention to quit (Redman et al., 2011). Sementara itu, penelitian yang mencoba untuk membahas dampak keadilan organisasi terhadap kepercayaan organisasi seperti yang dilakukan oleh Tlaiss and Elamin (2015) masih sedikit dilakukan (terbatas).

Beberapa peneliti dalam studi organisasi memiliki perbedaan dalam meneliti keadilan organisasi dan kepercayaan organisasi. Berkaitan dengan keadilan organisasi, beberapa penelitian 
Jurnal Ilmiah Ekonomi dan Bisnis

Vol. 14. No.2, September 2017: 121-130

EISSN : $2442-9813$

ISSN : $1829-9822$

empiris hanya membahas satu atau dua dimensi dari keadilan organisasi (CohenCharash and Spector, 2001; Cheng, 2014), sedangkan penelitian empiris lainnya membahas keseluruhan (ketiga) dimensi keadilan organisasi seperti distributive justice, procedural jusctice, dan interactional justice (Elamin and Tlaiss, 2015; Tlaiss and Elamin, 2015). Selanjutnya, berkaitan dengan kepercayaan organisasi, beberapa penelitian empiris membahas dua atau lebih dimensi dari kepercayaan organisasi seperti lateral trust, vertical trust, dan institutional trust (Ellonen et al., 2008; Fard and Karimi, 2015) atau trust in organization dan trust in supervisor (Tlaiss dan Elamin, 2015), sedangkan penelitian empiris lainnya hanya membahas satu dimensi kepercayaan organisasi (Redman et al., 2011). Karena beberapa alasan tersebut, penelitian yang berkaitan dengan ketiga dimensi dari keadilan organisasi (distributive justice, procedural jusctice, dan interactional justice) dan kedua dimensi dari kepercayaan organisasi (trust in organization dan trust in supervisor) masih dibutuhkan. Bahkan, meskipun beberapa penelitian empiris telah menunjukkan bahwa perepsi terhadap keadilan dan kepercayaan organisasi merupakan prediktor penting dari faktor yang berhubungan dengan pekerjaan (Elamin and Tlaiss, 2015; Elanain, 2009; Elanain, 2010; Gupta and Sing, 2013; Liu and Ding, 2012; Redman et al. 2011; Tlaiss and Elamin, 2015), masih ada beberapa pertanyaan penting yang belum terjawab. Salah satu pertanyaan penting adalah dapatkah hasil-hasil penelitian tersebut di generalisasi ke Negara-negara Asia Tenggara seperti Indonesia khususnya pada organisasi pendidikan tinggi?

Sumber daya manusia Organisasi pendidikan tinggi di Pekanbaru Indonesia khususnya Perguruan Tinggi Swasta seperti Sekolah Tinggi Ilmu
Ekonomi merupakan kunci sukses dalam menghadapi tuntutan peningkatan kualitas pendidikan yang ada di Indonesia sehingga dibutuhkan kepercayaan antara Dosen dengan perguruan tinggi agar memberikan dampak yang baik bagi organisasi. Hasil wawancara singkat peneliti dengan beberapa Dosen yang pernah mengajar di Sekolah Tinggi Ilmu Ekonomi dan saat ini telah pindah menjadi Dosen di beberapa Universitas yang ada di Kota Pekanbaru mengungkapkan bahwa salah satu penyebab mereka pindah adalah kurangnya rasa kepercayaan mereka terhadap pimpinan dan organisasi mereka. Hal ini menjelaskan bahwa kepercayaan organisasi masih menjadi salah satu permasalahan utama yang harus di selesaikan pada Sekolah Tinggi Ilmu Ekonomi di Kota Pekanbaru.

Penelitian yang membahas tentang dampak keadilan organisasi terhadap kepercayaan organisasi dari Negaranegara Non-Barat khususnya di Indonesia masih jarang ditemukan dalam publikasi ilmiah (Liu and Ding, 2012; Gupta and Singh, 2013; Tlaiss and Elamin, 2015). Mengingat karena terdapatnya kesenjangan pengetahuan (publikasi ilmiah) dalam studi organisasi dan manajemen sumber daya manusia mengenai hal tersebut maka penelitian ini mencoba untuk membuktikan apakah dimensi keadilan organisasi yang terdiri dari distributive justice, procedural jusctice, dan interactional justice berpengaruh terhadap tingkat kepercayaan karyawan pada organisasinya khususnya pada Sekolah Tinggi Ilmu Ekonomi di Kota Pekanbaru, Riau, Indonesia.

\section{TINJAUAN PUSTAKA}

Kepercayaan telah lama dikenal sebagai komponen penting dari fungsi efektif sebuah organisasi (Tlaiss dan Elamin, 2015) dan elemen penting dalam hubungan manusia yang konstruktif (Moye dan Henkin, 2006). Selain memperkuat efektivitas proses pengambilan 
keputusan (Mishra dan Morrissey, 1990), kepercayaan juga memungkinkan seorang karyawan untuk terbuka dalam bertukar pendapat (ide-ide), memperbaiki kualitas dan kuantitas pertukaran informasi, dan memperkuat keinginan karyawan untuk bekerja sama dan kapasitas mereka untuk menangani krisis (Mishra and Morrissey,1990; $\quad$ McAllister,1995; Whitener,1998; Aryee et al.,2002). Organisasi selalu mencari cara untuk meningkatkan kerjasama dan kolaborasi antara karyawan mereka, ketidakpercayaan didalam manajemen ditemukan sebagai kendala utama dalam hubungan di dalam organisasi (McCune, 1998). Dengan kata lain karyawan yang tidak percaya terhadap organisasi dan manajemen kemungkinan akan memiliki komitmen yang rendah dan hasil kerja yang tidak efektif (Tlaiss dan Elamin, 2015). Sama halnya dengan hasil penelitian yang dilakukan oleh Davis et al (2000) yang menemukan bahwa praktik-praktik manajemen memiliki dampak langsung terhadap kepercayaan. Berdasarkan hasil penelitian tersebut, juga ditemukan bahwa hasil (output) dari organisasi seperti profitabilitas, penjualan dan turnover intention secara langsung berhubungan pada kepercayaan dalam manajemen.

Keadilan organisasi merupakan sesuatu yang mendasari persepsi karyawan tentang adanya suatu perlakuan yang adil di tempat kerjanya (Collquit, et. al., 2001). Keadilan organisasi didefenisikan sebagai persepsi dan rekasi perilaku oleh bawahan terhadap perlakuan adil yang dilakukan oleh organisasi (James, 1993). Penelitian-penelitian yang membahas mengenai keadilan organisasi sering difokuskan pada keadilan di tempat kerja dan persepsi karyawan mengenai keadilan didalam praktek, proses dan prosedur organisasi (Croponzano et al. 2002; Suliman, 2013; Tlaiss dan Elamin, 2015). Dengan kata lain, ketika bawahan merasakan keadilan di tempat kerja mereka dan seluruh situasi terlihat adil dan merata dengan yang lain, mereka akan lebih mungkin untuk menunjukkan perilaku kerja yang baik (Tlaiss dan Elamin, 2015). Hal ini telah dijelaskan oleh penelitian-penelitian sebelumnya yang menyatakan bahwa keadilan di tempat kerja dan persepsi bawahan tentang keadilan cenderung untuk memprediksi sikap dan perilaku di tempat kerja termasuk inovasi, peningkatan kepuasan kerja dan kinerja (Suliman, 2013), dan meningkatkan komitmen karyawan (Croponzano et al., 2002). Beberapa penelitian juga menjelaskan bahwa keadilan organisasi berhubungan positif terhadap organizational citizenship behavior (Elamin dan Tlaiss, 2015), komitmen organisasi dan standar moral yang lebih tinggi (Croponzano et al., 2002).

Beberapa studi di bidang perilaku organisasi yang membahas mengenai keadilan di tempat kerja fokus pada tiga dimensi keadilan organisasi (Neihoff dan Moorman's, 1993; Tlaiss dan Elamin, 2015). Dimensi pertama dalam keadilan organisasi yaitu distributive justice. Distributive justice (keadilan distributive) merupakan persepsi bawahan mengenai sejauh mana reward (hasil) yang diterimanya dialokasikan secara adil oleh organisasi (Neihoff \& Moorman, 1993). Di dalam organisasi, karyawan akan menentukan apakah mereka diperlakukan adil dengan membandingkan rasio input yang mereka berikan (misalnya, waktu, sumber daya) dihubungkan dengan apa yang mereka terima (misalnya gaji, promosi, kesempatan pengembangan diri), selanjutnya perbandingan rasio ini juga dibandingkan dengan perbandingan rasio yang sama pada orang lain (Tlaiss dan Elamin, 2015; Noe et al., 2011). Dimensi yang kedua yaitu prosedural justice. Prosedural justice (keadilan prosedural) merupakan persepsi bawahan mengenai sejauh mana proses pengambilan keputusan yang dilakukan oleh organisasi dilakukan secara akurat, etis dan adil (Leventhal, 1980; Neihoff \& Moorman, 1993; Noe et al., 2011; Tlaiss dan Elamin, 2015). Selanjutnya, dimensi yang terakhir yaitu interactional justice. Interactional justice (keadilan interaksi) merupakan persepsi bawahan mengenai keadilan atau kewajaran perlakuan yang diterima oleh bawahan (dinamika interpersonal dan persepsi kualitas komunikasi) yang dilakukan oleh organisasi selama porses pengambilan 
Jurnal Ilmiah Ekonomi dan Bisnis

Vol. 14. No.2, September 2017: 121-130

EISSN : $2442-9813$

ISSN : $1829-9822$

keputusan (Bies dan Moag, 1986; Neihoff \& Moorman, 1993; Tlaiss dan Elamin, 2015).

\section{METODE PENELITIAN}

Penelitian ini menggunakan pendekatan kuantitatif dengan berdasar kepada research gap dan fenomena yang terjadi. Pada tahap analisis digunakan pendekatan analisis dengan cara deskripsi analisis dan menggabungkannya dengan menggunakan analisis statistik untuk mengetahui kekuatan dan kelemahan hubungan antara variabel yang mempengaruhi penelitian ini.

Teknik Pengambilan sampel dengan metode kuesioner, Malholtra (2005) mendefinisikan "Kuesioner adalah teknik terstruktur untuk memperoleh data yang terdiri dari serangkaian pertanyaan, tertulis atau verbal, yang dijawab responden".

Kuesioner disebar dengan cara menyusun pertanyaan yang telah tersusun lengkap dengan pilihan jawaban yang bertujuan untuk mempermudah responden untuk menjawab. Semua pertanyaan yang sudah dijawab oleh responden akan dijaga kerahasiannya mulai dari data pribadi responden hingga jawaban yang telah responden berikan. Sampel yang berupa kuesioner akan di bagikan secara langsung kepada responden sebagai salah satu media penyebaran kuesioner.

Jumlah populasi dalam penelitian ini sebanyak 173 orang dosen yang tersebar pada 7 Sekolah Tinggi Ilmu Ekonomi yang ada di Kota Pekanbaru. Karena jumlah populasi masih dalam jangkauan peneliti, maka dalam penelitian ini akan disebarkan sebanyak 173 kuesioner ke seluruh dosen yang ada pada Sekolah Tinggi Ilmu Ekonomi yang ada di Kota Pekanbaru.

Analisis deskriptif ini digunakan untuk memberikan gambaran mengenai responden dalam penelitian dan hasil penelitian di lapangan yang berkaitan dengan kecenderungan faktor analisis pengaruh keadilan organisasi terhadap kepercayaan organisasi. Sehingga dengan demikian analisis statistik deskriptif pada penelitian ini digunakan untuk memberikan gambaran tentang variable yang terkait dengan; a) distributive justice, b) procedural justice, c) interactional justice, dan d) kepercayaan organisasi.

Untuk menguji hipotesis analisis Structural Equation Modelling-Partial Least Square (SEM-PLS) digunakan. Tujuan penggunaan anaslisis SEM dalam penelitian ini karena variabel yang digunakan dalam penelitian ini merupakan unobserverd variable (variabel yang tidak dapat diamati secara langsung) atau dalam pengukurannya menggunakan indikator untuk menilainya.

Analisis SEM-PLS terdiri dari dua tahap evaluasi: (1) outer model evaluation; dan (2) inner model evaluation (Abdillah et al., 2016). Tahap pertama yaitu evaluasi outer model, dilakukan untuk melihat validitas dan reliabilitas data. Uji validitas dalam outer model evaluation dilakukan dengan melakukan uji validitas konvergen dan validitas diskriminan. Tahap kedua yaitu evaluasi inner model dilakukan untuk menguji hipotesis dalam penelitian.

\section{HASIL DAN PEMBAHASAN}

Tahap pertama adalah melakukan evaluasi terhadap model pengukuran (outer model) dengan cara menguji validitas dan reliabilitas untuk setiap variabel penelitian. Selanjutnya, tahap kedua adalah melakukan evaluasi terhadap model struktrual (inner model). Evaluasi terhadap outer model dalam penelitian ini bertujuan untuk melihat apakah instrumen yang digunakan untuk variabel iklim organisasi, kinerja karyawan dan stres kerja dalam penelitian ini memiliki tingkat ketepatan dan akurasi serta konsistensi yang baik (Hartono, 2011; Abdillah dan Hartono, 2015). Evaluasi terhadap outer model dalam PLS dilakukan melalui uji validitas 
konvergen, validitas diskriminan, dan reliabilitas.

Tabel 1. Hasil Loading factor dan cross loading

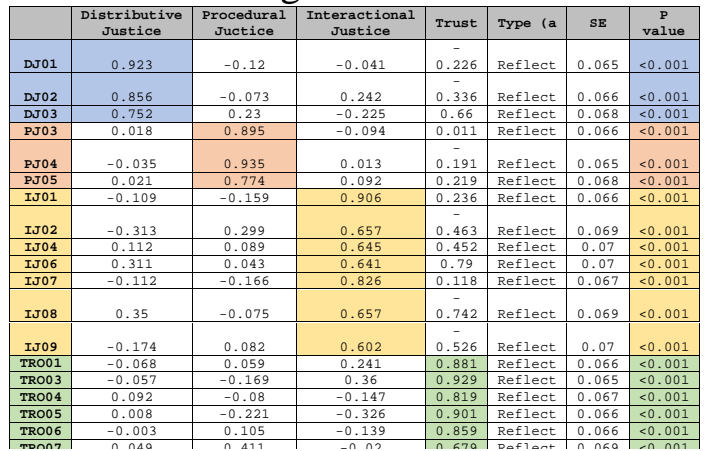

Sumber: Data Olahan (2017)

Nilai cross loading korelasi instrumen-instrumen terhadap variabelnya lebih baik dibandingkan ke variable lainnya. Hasil ini menjelaskan bahwa skor loading masing-masing instrumen pada suatu variabel akan berbeda dengan instrumen-instrumen tersebut di variabel lain dan mengumpul pada variabel yang dimaksud (Hartono, 2011; Abdillah dan Hartono, 2015). Sehingga, dapat disimpulkan bahwa seluruh instrumen setiap variabel yang terdiri dari distributive justice, procedural justice, interactional juctice dan trust (kepercayaan) pada model penelitian ini memenuhi persyaratan validitas diksriminan (Hair et al.,2012).

Evaluasi terhadap model struktural dalam penelitian ini bertujuan untuk memprediksi hubungan kausalitas antar variabel yang telah dihipotesiskan.

Tabel 1. Evaluasi model structural

\begin{tabular}{|c|c|c|c|c|c|c|}
\hline \multirow{2}{*}{ Evaluasi } & Uji Hipotesis & $\begin{array}{c}\text { Path } \\
\text { Coefficient }\end{array}$ & $\begin{array}{c}\text { Standard } \\
\text { Errors }\end{array}$ & $\begin{array}{c}\text { P- } \\
\text { value }\end{array}$ & $\begin{array}{c}\text { Effect } \\
\text { Size }\end{array}$ & $\begin{array}{c}\text { R- } \\
\text { Square }\end{array}$ \\
\hline Model 1 & OJ $\rightarrow$ Kepercayaan & 0,891 & 0,066 & $<0,01$ & 0,795 & 0,795 \\
\hline \multirow{3}{*}{ Model 2 } & DJ $\rightarrow$ Kepercayaan & 0,153 & 0,077 & $<0,05$ & 0,065 & \multirow{2}{*}{0,835} \\
\cline { 2 - 6 } & PJ $\rightarrow$ Kepercayaan & 0,235 & 0,076 & $<0,01$ & 0,114 & \multirow{2}{*}{} \\
\cline { 2 - 6 } & IJ $\rightarrow$ Kepercayaan & 0,755 & 0,068 & $<0,01$ & 0,656 & \\
\hline
\end{tabular}

Hasil evaluasi model struktural dalam penelitian ini menunjukkan bahwa hipotesis pertama (H1) didukung secara statistik dengan nilai $p$-value signifikan pada level alpha 1 persen ( $p$-value < $0,01)$ dengan koefisien jalur sebesar
0,891. Hal ini membuktikan bahwa OJ (organizational justice) berpengaruh positif terhadap kepercayaan. Selanjutnya, nilai effect size sebesar 0,795 menunjukkan bahwa pengaruh organizational justice terhadap kepercayaan berkategori kuat (Abdillah et al., 2016).

Hipotesis kedua $\left(\mathrm{H}_{2}\right)$ dalam penelitian ini didukung secara statistik dengan nilai $p$-value signifikan pada level alpha 5 persen $(p$-value $<0,05)$ dengan koefisien jalur sebesar 0,153. Hal ini membuktikan bahwa DJ (distributive justice) berpengaruh positif terhadap kepercayaan. Selanjutnya, nilai effect size sebesar 0,065 menunjukkan bahwa pengaruh distributive justice terhadap kepercayaan berkategori lemah (Abdillah et al., 2016).

Hipotesis ketiga $\left(\mathrm{H}_{3}\right)$ dalam penelitian ini didukung secara statistik dengan nilai $p$-value signifikan pada level alpha 1 persen ( $p$-value $<0,01)$ dengan koefisien jalur sebesar 0,235. Hal ini membuktikan bahwa PJ (procedural justice) berpengaruh positif terhadap kepercayaan. Selanjutnya, nilai effect size sebesar 0,114 menunjukkan bahwa pengaruh procedural justice terhadap kepercayaan berkategori sedang/moderat (Abdillah et al., 2016).

Hipotesis keempat $\left(\mathrm{H}_{4}\right)$ dalam penelitian ini didukung secara statistik dengan nilai $p$-value signifikan pada level alpha 1 persen ( $p$-value $<0,01)$ dengan koefisien jalur sebesar 0,755. Hal ini membuktikan bahwa IJ (interactional justice) berpengaruh positif terhadap kepercayaan. Selanjutnya, nilai effect size sebesar 0,656 menunjukkan bahwa pengaruh interactional justice terhadap kepercayaan berkategori kuat (Abdillah et al., 2016).

\section{Pembahasan}

Hasil Pada model pertama dalam penelitian ini menunjukan bahwa organizational justice berpengaruh positif 
Jurnal Ilmiah Ekonomi dan Bisnis

Vol. 14. No.2, September 2017: 121-130

EISSN : $2442-9813$

ISSN : $1829-9822$

terhadap kepercayaan organisasi. Hasil penelitian ini sejalan dengan penelitian yang dilakukan oleh Tlaiss dan Elamin (2015). Hal ini menjelaskan bahwa anggota-anggota organisasi (dosendosen) yang merasakan keadilan di dalam organisasi mereka akan menyebabkan mereka percaya pada organisasinya (Cohen-Charash and Spector, 2001; Colquitt, 2001). Begitu juga sebaliknya, anggota-anggota organisasi yang merasakan ketidakadilan di dalam organisasi mereka akan menyebabkan ketidakpercayaan mereka pada organisasinya.

Selanjutnya, dalam penelitian ini menelaah lebih jauh pengaruh dimensidimensi yang ada pada organizational justice terhadap kepercayaan organisasi. Pada model kedua dalam penelitian ini menunjukkan bahwa baik distributive justice, procedural justice, dan interactional justice berpengaruh positif terhadap kepercayaan organisasi. Hal ini menjelaskan bahwa kepercayaan anggota-anggota organisasi terhadap organisasinya disebabkan oleh (1) persepsi bawahan mengenai sejauh mana reward (hasil) yang diterimanya dialokasikan secara adil oleh organisasi (Neihoff \& Moorman, 1993); (2) sejauh mana proses pengambilan keputusan yang dilakukan oleh organisasi dilakukan secara akurat, etis dan adil (Leventhal, 1980; Neihoff \& Moorman, 1993; Noe et al., 2011; Tlaiss dan Elamin, 2015); (3) keadilan atau kewajaran perlakuan yang diterima oleh bawahan (dinamika interpersonal dan persepsi kualitas komunikasi) yang dilakukan oleh organisasi selama proses pengambilan keputusan (Bies dan Moag, 1986; Neihoff \& Moorman, 1993; Tlaiss dan Elamin, 2015).

\section{KESIMPULAN DAN SARAN Simpulan}

Berdasarkan hasil penelitian dan pembahasan yang telah dilakukan pada bab sebelumnya maka kesimpulan penelitian ini yaitu:

1. Organizational justice berpengaruh positif terhadap kepercayaan organisasi. Hal ini menjelaskan bahwa bawahan yang merasakan keadilan di dalam organisasi mereka akan menyebabkan mereka percaya pada organisasinya.

2. Distributive justice berpengaruh positif terhadap kepercayaan organisasi. Hal ini menjelaskan bahwa kepercayaan bawahan terhadap organisasinya disebabkan oleh persepsi bawahan mengenai sejauh mana reward (hasil) yang diterimanya dialokasikan secara adil oleh organisasi.

3. Procedural justice berpengaruh positif terhadap kepercayaan organisasi. Hal ini menjelaskan bahwa kepercayaan bawahan terhadap organisasinya disebabkan oleh persepsi bawahan mengenai sejauh mana proses pengambilan keputusan yang dilakukan oleh organisasi dilakukan secara akurat, etis dan adil.

4. Interactional justice berpengaruh positif terhadap kepercayaan organisasi. Hal ini menjelaskan bahwa kepercayaan bawahan terhadap organisasinya disebabkan oleh persepsi bawahan mengenai keadilan atau kewajaran perlakuan yang diterima oleh bawahan (dinamika interpersonal dan persepsi kualitas komunikasi) yang dilakukan oleh organisasi selama proses pengambilan keputusan.

\section{Saran}

Hal-hal yang dapat disarankan berdasarkan hasil penelitian dan pembahasan meliputi:

1. Organizational justice dalam penelitian ini merupakan penyebab dari munculnya kepercayaan bawahan pada organisasinya, sehingga pimpinan 
perguruan tinggi pada sekolah tinggi ilmu ekonomi yang ada di kota pekanbaru dalam pengambilan keputusan harus lebih memperhatikan Distributive justice, Procedural justice dan Interactional justice.

2. Agar terjadi Distributive justice, maka pimpinan perguruan tinggi harus memperhatikan keadilan dalam pemberian jadwal kerja, beban kerja, penghargaan, serta tanggung jawab pekerjaan.

3. Agar terjadi Procedural justice, maka pimpinan perguruan tinggi harus: objektif, etis dan adil serta konsisten dalam proses pengambilan keputusan dengan mempertimbangkan seluruh kepentingan baik organisasi maupun bawahan.

4. Interactional justice merupakan variabel penting dalam penyebab munculnya kepercayaan bawahan pada organisasi sehingga interaksi antara bawahan dan organisasi dalam proses pengambilan keputusan harus dilakukan secara terbuka, objektif, etis dan adil.

\section{DAFTAR PUSTAKA}

Abdillah, M.R. (2016) "Dampak kepercayaan organisasi terhadap organizational silence kepuasan kerja dan komitmen organisasi". Laporan Hasil Penelitian Mandiri.

Abdillah, W. dan J. Hartono. (2015) Partial Least Square (PLS) : Alternatif Structural Equation Modeling (SEM) dalam Penelitian Bisnis. Yogyakarta : Andi.

Agarwal, U.A. (2014), "Linking justice, trust and innovative work behavior to work engagement", Personnel Review, Vol. 43 No. 1, pp. 41-73.
Aryee, S., Budhwar, P.S. and Chen, Z.X. (2002), "Trust a mediator of the relationship between organizational justice and work outcomes: test of a social exchange model", Journal of Organizational Behavior, Vol. 23 No. 3, pp. 267285.

Bidarian, S. and Jafari, P. (2012) "The relationship between organizational justice and organizational trust", Procedia Social and Behavioral Sciences, Vol. 47, pp. 1622-1626.

Bies, R.J. and Moag, J.S. (1986), "Interactional justice: communication criteria of fairness", Research on Negotiation in Organizations, Vol. 1, pp. 4355.

Blau, P.M. (1964), Exchange And Power in Social Life, Wiley, New York, NY.

Cheng, S.Y. (2014), "The mediating role of organizational justice on the relationship between administrative performance appraisal practices and organizational commitment", The International Journal of Human Resource Management, Vol. 25 No. 8, pp. 1131-1148.

Cohen-Charash, Y. and Spector, P. (2001), "The role of justice in organizations: a meta-analysis", Organization Behavior and Human Decision Processes, Vol. 86 No. 2, pp. 278-321.

Colquitt, J.A. (2001), "On the dimensionality of organizational justice: a construct validation of a measure", Journal of Applied Psychology, Vol. 86 No. 3, pp. 386-400. 
Jurnal Ilmiah Ekonomi dan Bisnis

Vol. 14. No.2, September 2017: 121-130

EISSN : $2442-9813$

Cropanzano, R. and Mitchell, M.S. (2005), "Social exchange theory: an interdisciplinary review", Journal of Management, Vol. 31 No. 6, pp. 874-900.

Cropanzano, R., Prehar, C.A. and Chen, P.Y. (2002), "Using social exchange theory to distinguish procedural from interactional justice", Group and Organization Management, Vol. 27 No. 3, pp. 324-351.

Davis, J.H., Schoorman, F.D., Mayer, R.C. and Tan, H.H. (2000), "The trusted general manager and business unit performance: empirical evidence of a competitive advantage", Strategic Management Journal, Vol. 21 No. 5, pp. 563-576.

Elamin, A.M. and Tlaiss, H.A. (2015), "Exploring the relationship between organizational citizenship behavior and organizational justice in the Islamic Saudi Arabian context", Employee Relations, Vol. 37 No. 1, pp. 2-29.

Ellonen, R., Blomqvist, K., and Puumalainen, K. (2008), "The role of trust in organizational innovativeness", European Journal of Innovation Management, Vol. 11 Iss 2 pp. $160-181$

Fard, P.G., and Karimi, F. (2015) "The Relationship between Organizational Trust and Organizational Silence with Job Satisfaction and Organizational Commitment of the Employees of University". International Education Studies, Vol. 8 No. 11, pp. 219-227.
Ghozali, I. dan Fuad (2012) Structural Equation Modeling : Teori, Konsep, dan Aplikasi Dengan Lisrel 8.80, Semarang : UNDIP Press.

Greenberg, J. (1987), "A taxonomy of organizational justice theories", Academy of Management Review, Vol. 12 No. 1, pp. 9-22.

Gupta, V. and Singh, S. (2013), "An empirical study of the dimensionality of organizational justice and its relationship with organizational citizenship behaviour in the Indian context", The International Journal of Human Resource Management, Vol. 24 No. 6, pp. 1277-1299.

Hair, J. F., M. Sarstedt, C. M. Ringle, dan J. A. Mena. (2012) "An Assessment of the Use off Partial Least Squares Structural Equation Modeling in Marketing Research", Journal of the Academy of Marketing Science. Vol. 40 No. 1, pp. 414-433.

Hair, J. F., M. Sarstedt, L. Hopkins, V. G. Kuppelwieser. (2014) "Partial Least Squares Structural Equation Modeling (PLS-SEM): An Emerging Tool in Business Research". European Business Review. Vol. 26 No. 2, pp. 106121.

Hartono J. (2011) Konsep dan Aplikasi Structural Equation Modeling Berbasis Varian dalam Penelitian Bisnis. Yogyakarta : UPP STIM YKPN.

Hartono. J. (2015) Metodologi Penelitian Bisnis : Salah Kaprah dan Pengalaman-Pengalaman. Edisi 6. Yogyakarta : BPFE. 
James, K. (1993), "The social context of organizational justice: cultural intergroup, and structural effects", in Cropanzano, R. (Ed.), Justice in the workplace, Erlbaum, Hillsdale, NJ, pp. 2150.

Latan, H. dan I. Ghozali. (2012) Partial Least Squares : Konsep, Teknik dan Aplikasi Menggunakan Program SmartPLS 2.0 M3. Semarang : UNDIP Press.

Leventhal, G.S. (1980), "What should be done with equity theory? New approaches to the study of fairness in social relationshipsin Gergen, K.J., Greenberg, M.S. and Willis, R.H. (Ed.), Social Exchange: Advances in Theory and Research, NY Plenum Press, New York, pp. 27-55.

Liu, N.-T. and Ding, C.G. (2012), "General ethical judgments, perceived organizational support, interactional justice, and workplace deviance", The International Journal of Human Resource Management, Vol. 23 No. 14, pp. 2712-2735.

McAllister, D.J. (1995), “Affect-and cognition-based trust as foundations for interpersonal cooperation in organizations", Academy of Management Journal, Vol. 38 No. 1, pp. 2459.

McCune, J. (1998), "The elusive thing called trust", Management Review, Vol. 87 No. 7, pp. 11-16.

Mayer, R.C., Davis, J.H. and Schoorman, F.D. (1995), "An integrative model of organizational trust",
Academy of Management Review, Vol. 20 No. 3, pp. 709-734.

Mishra, J. and Morrissey, M.A. (1990), "Trust in employee/employer relationships: a survey of West Michigan managers", Public Personnel Management, Vol. 19 No. 3, pp. 443-485.

Moye, M.J. and Henkin, A.B. (2006), "Exploring associations between employee empowerment and interpersonal trust in managers", Journal of Management Development, Vol. 25 No. 2, pp. 101-117.

Mustafa EQ, Z. (2009) Mengurai Variabel hingga Instrumen, Graha Ilmu, Yogyakarta.

Niehoff, B. and Moorman, R.H. (1993), "Justice as a mediator of the relationship between methods of monitoring and organizational citizenship behavior", Academy of Management Journal, Vol. 36 No. 3 , pp. 527-556.

Noe, R.A., Hollenbeck, J.R., Gerhart, B., and Wright, P.M. (2011) Manajemen Sumber Daya Manusia ; Mencapai Keunggulan Bersaing, Edisi Keenam, Buku Dua, Terjemahan, Salemba Empat, Jakarta.

Redman, T., Dietz, G., Snape, E. and van der Borg, W. (2011), "Multiple constituencies of trust: a study of the Oman military", The International Journal of Human Resource Management, Vol. 22 No. 11, pp. 2384-2402.

Robinson, S.L. (1996), "Trust and breach of the psychological contract", 
Jurnal Ilmiah Ekonomi dan Bísnís

Vol. 14. No.2, September 2017: 121-130

EISSN : $2442-9813$

ISSN : $1829-9822$

Administrative

Science

Quarterly, Vol. 41, pp. 574-599.

Sari, R.N., Anugerah, R., Yusralaini and Gusrifan, H. (2013) "The Mediating Effects of Feedback and Procedural Justice on the Relationship between Formal Performance Evaluation System and Trust between Superior and Subordinate Managers", Mediterranean Journal of Social Sciences, Vol. 4 No. 10, pp. $497-$ 504.

Sekaran, U. (2006) Metode Riset Bisnis, Salemba Empat, Jakarta.

Solihin, M. dan D. Ratmono. (2013). Analisis SEM-PLS dengan WarpPLS 3.0, Yogyakarta : Andi.

Suliman, A. (2013), “Organizational justice and innovation in the workplace: the case of the UAE", Journal of Management Development, Vol. 32 No. 9, pp. 945-959.

Sugiyono (2011) Metode Penelitian Bisnis. Alfabeta. Bandung.

Tlaiss, H.A. dan Elamin, A.M. (2015) "Exploring organizational trust and organizational justice among junior and middle managers in Saudi Arabia". Journal of Management Development, Vol. 34 No. 9, pp. 1042 - 1060

Wat, D. and Shaffer, M.A. (2005), "Equity and relationship quality influences on organizational citizenship behaviors: the mediating role of trust in the supervisor and empowerment", Personnel Review, Vol. 34 No. 4, pp. 406-422.
Whitener, E.M. (1998), "The impact of human resource activities on employee trust", Human Resource Management Review, Vol. 7 No. 4, pp. 389-404.

Wibowo, H., S. (2014). SEM With Lisrel, Modul Pelatihan Pusat Pendidiikan dan Pelayanan (P3M) Universitas Indonesia, Depok.

Wong, Y.T. (2012), "Job security and justice: predicting employees' trust in Chinese international joint ventures", The International Journal of Human Resource Management, Vol. 23 No. 19, pp. 4129-4144.

Wong, Y.T., Wong, C.S. and Ngo, H.Y. (2002), "Loyalty to supervisor and trust in supervisor of workers in Chinese joint ventures: a test of two competing models", The International Journal of Human Resource Management, Vol. 13 No. 6, pp. 883-900. 